UDC 502.17

\title{
A review in Southeastern Nigeria: environmental problems and management solutions
}

\author{
Nwankwo Nnabueze Kalu, Yulia L. Zakirova
}

\author{
Peoples' Friendship University of Russia (RUDN University) \\ 8 Podolskoye Highway, bldg. 5, Moscow, 115093, Russian Federation
}

\begin{abstract}
This article aims at understanding the environmental problems in the Southeastern part of Nigeria and how they affect public activities and values. It is meant to highlight the standard of living, environmental conditions, and the possible solutions with challenges to sustaining the environment. The Southeastern part of Nigeria is becoming heavily influenced by climate change. Problems and difficulties are stretching from persistent flooding to destruction of natural habitat and environmentally related health issues. In other words, this article answers questions related to environmental problems and reveals the reason why there are frequent occurrences of these problems. Another crucial part is in the explanation of the social behaviour and complex risks associated with ignorance of indirect human activities, focusing more on the issues which could be in the water, soil, and air. In concerns towards environmental problems in Southeastern Nigeria, this article will lay more emphasis on the most persistent environmental issues and concerns affecting these areas and how to manage them.
\end{abstract}

Keywords: soil degradation, pollution, environment, problems, management

\section{Introduction}

A range of human activities contaminate the natural environment directly or indirectly, and this brings about change in the climate. Damage of natural habitats, farmlands for agriculture, properties and contamination of water and water bodies, including air and soil, are all linked to a substantial increase in natural disasters such as flooding and soil erosion. Due to the growing population, a more significant number of people are leaving the rural areas to the urban areas in search of better standards of living. Prior studies have discussed the potential influence of government policies on the social behavior of Nigerians but haven't been able to look into chaos and disorder caused as a result of inadequate Environmental Management Systems and the level of ignorance displayed by the people which has, in turn, led to the increase in occurrence of natural disasters.

Soil erosion is generally brought about by rain during the rainy season and wind during the dry season. Soil erosion mainly gully is a major ecological prob-

(C) Kalu N.N., Zakirova Y.L., 2019

(c) (i) This work is licensed under a Creative Commons Attribution 4.0 International License https://creativecommons.org/licenses/by/4.0/ 
lem frustrating most states in Nigeria, especially the Southeastern states of Anambra, Imo, Ebonyi, Abia, and Enugu in the tropical areas of Southeastern Nigeria.

Ascertaining the values and impacts of environmental problems from a practical point of view and understanding the specificity of an approach to addressing the issues with public engagement will help on the contribution to directly or indirectly solve environmental major concerns. Air pollution intensifies the occurrence of respiratory diseases and poses a threat to the population of these areas, thereby bringing an extra burden for the federal government to handle.

\section{Study area}

Southeastern Nigeria covers and includes the five states - Abia, Anambra, Ebonyi, Enugu, and Imo. These states constitute one of the six geopolitical zones in Nigeria. Located between latitudes 4040' to 7020' north of the equator and longitudes 6000' to 8020' east of the Greenwich Meridian.

The total area covers $50,000 \mathrm{~km}^{2}$ of Nigeria's total land area of $923,768 \mathrm{~km}^{2}$ [1]. Southeastern Nigeria is bordered to its north by Benue and Kogi states, and down south by Rivers state; towards the East by Cross River state and towards the west by Delta state. It covers a landmass of $22,525 \mathrm{~km}^{2}$ [2].

The population density of the study area referring to the 2006 population census is $16,381,729$ persons, $8,306,306$ males and 8,075,423 females [3]. The Southeastern part of Nigeria has a tropical wet and dry climate due to the rainy and dry seasons. Rainfall occurs between the months of March and October and four months of the dry season between November and February. The mean annual rainfall volumes fluctuate between 1800 and 2000 meters [4]. The average value for the temperature is $27^{\circ} \mathrm{C}$. Average relative humidity fluctuates between $60-70 \%$ in January and $80-90 \%$ in July, respectively [5].

The Southeastern soils made up mainly of iron are in the form of sandy clays, loamy, clay, and sandstones. Classification can further be based on landscape features, geological formation, and degree of profile development into hydromorphic soils, lithosols, ferralitic soils, and juvenile soils [3].

\section{Environmental problems in Southeastern Nigeria}

Water pollution. Modern agriculture practices make use of chemical products like pesticides, insecticides, and fertilizers to deal with pests, weeds, and insects. Certain chemicals when sprayed to kill insects, pests and weeds do not vanish entirely; rather they leach into the ground, destroying the soil, plant roots and harm microorganisms in the soil. Due to the lack of working sanitary landfills, during the rainy season waste materials are washed into a nearby water body. Illegal disposal of industrial, sewage, and municipal waste into local water bodies is rampant. During the dry season, farmers irrigate these contaminated waters into the farmland due to lack of rainfall during this season. In the rural areas, streams and rivers are the major sources of drinking water, but for the past few years, the pollution of these water bodies is on the increase leading locals and villagers to buy bottled water at high prices. Polluted water bodies are breeding grounds for disease-causing pathogens.

Air pollution. Pollution of air takes a considerable number of years for the mean annual concentration to exceed the WHO standard. In Southeastern Nigeria there 
are cities with a higher than average level of intensity of PM10 and PM2.5. Vehicle fumes and home generators' fumes are the most noticeable pollutants and toxins. Substantial metals, nitrates, and plastic are poisons in charge of pollution in these areas. Air contamination is created by gases released by businesses and manufacturing plants and by combustion of all types. The negative impact and consequences of air pollution on health have increased over the last 20 years [6].

Estimates from the WHO suggest that the exposure to domestic air pollution from food preparation with solid fuels causes 4.3 million premature deaths annually in the world [7]. Combusting of fossil fuel in the house affects health in numerous ways and contributes to acute respiratory diseases and infections, cardiovascular diseases, pneumonia, stunted growth in children, chronic bronchitis in women, chronic obstructive pulmonary disease (COPD), cataracts and other visual impairments, lung cancer, tuberculosis, and perinatal infections. Among the 4.3 million who die from the effects and consequences of smoke emission each year, 500,000 are children under five that die as a result of acute respiratory infections (ARI).

Young children are predominantly vulnerable for two reasons: first, due to the cultural heritage and mentality of women being the home keepers, children are usually with their mothers during the food preparation process and thereby inhaling large loads of particulate emission. In the latest systematic review, it was discovered that children's particulate emission exposure to PM10 and PM2.5 is like their mothers'. Second, in similarity and assessment with adults, the bodies of young children are more prone to ARI, leading to a high death rate in this age group.

Southern Nigerian port city of Onitsha (Anambra State) - was ranked the worst city in the world for the unbelievable levels of PM10 particulate matter in its air (Figure 1) [8].

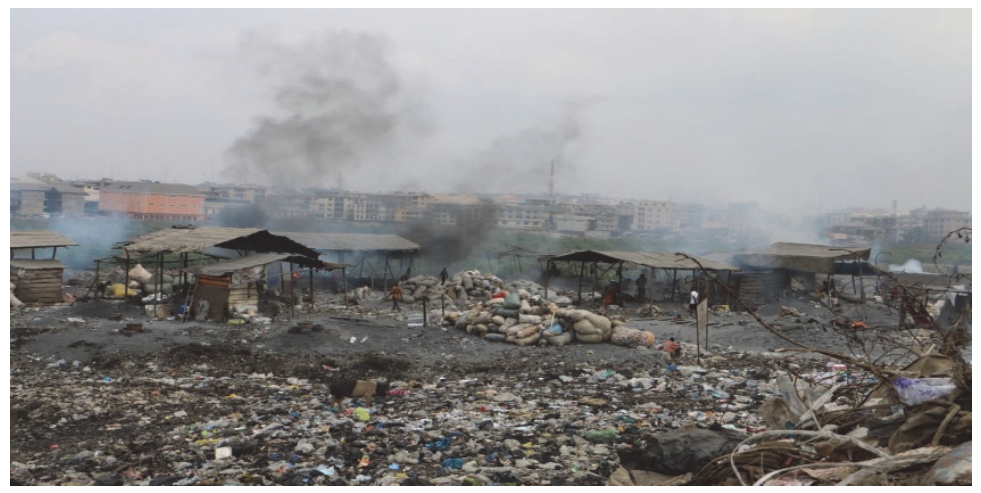

Figure 1. Air pollution in Southern Nigerian port city of Onitsha

The city of Onitsha's mean annual concentration was recorded at $594 \mathrm{mi}-$ crograms per cubic meter by the World Health Organization - tremendously higher than the WHO's yearly guideline limit for PM10s of $20 \mu \mathrm{g} / \mathrm{m}^{3}$. PM10 refers to coarse dust particles between 10 and 2.5 micrometers in diameter, while PM2.5s are smoother and more dangerous when inhaled. PM2.5 settles deep in a person's lungs and causes complicated health issues. Sources of PM10 and PM2.5 are dust storms, gases emitted by vehicles, all types of combustion, and industrial activities such as cement manufacturing, construction, mining, and smelting. Onitsha ranks 
the highest on most of the above mentioned. Other Southeastern cities with such concentration of air pollution include Aba and Umuahia of Abia State, which also featured in the WHO's 20 worst offenders for PM10s.

Soil degradation. Urbanization has general effects on soil degradation development. Primary, it strips the soil's vegetation cover, squeezes and compresses the soil during construction activities, and changes the natural drainage pattern. Furthermore, the soil is covered in a concrete layer which increases the volume of surface runoff during the rainy season. This results in more erosion at the topsoil. Soil erosion and erosion processes are the main limitations to sustainable development and bring about ecological challenges. Heavy metals and chemicals are additionally conveyed with soil particles, beginning at upper sediment levels, which lead to water eutrophication and disruption of sensitive aquatic ecosystems. Erosion regularly occurs in areas that are always prone to bush burning, uncontrolled farming, and industrial activities on high slopes [9]. Mining activities, digging and construction activities with bush burning of extensive vegetation by farmers for agricultural practices are common practices in Southeastern Nigeria.

In river processes, erosion, transportation, and deposition all take place mostly in water bodies, moving from the upper course to the lower course [10]. Erosion monitoring is very crucial in identifying vulnerable areas and for determining the yield of deposits. Sediment generated and soil erosion make up essential factors that may be used for water quality control activities [11].

Characteristics of soil erosion are very noticeable in the southern part of Nigeria, where poor land management and utilization appear to be a huge problem. Studies have shown that the absence of functioning guidelines to put off destructive usage of land resources makes it even harder for the public to understand the consequences of land misuse. Nigeria has remained one of the countries with maximum alarming records for land mismanagement in Africa (Figure 2) [12].

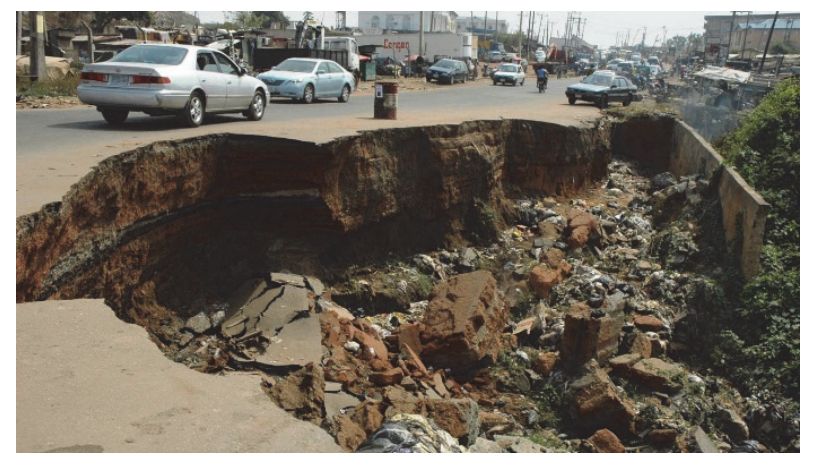

Figure 2. Soil erosion in Abia state

In 2017 the Federal Government of Nigeria approved 5.56 bln naira (over $\$ 15400$ 000) for erosion control in six states of Southeastern Nigeria.

Flooding. Proper understanding of the possible links between floods and infectious diseases is essential under the context of climate change, especially in Nigeria. More than 100 people have died over the past ten years in floods, and floodrelated cases in Southern Nigeria after two major rivers outflowed their banks [13]. Scientists and authorities say moderate and severe floods can extensively increase 
diarrheal risks in one week with regionally varied effects, and severe floods may bring about higher risks [14].

Land degradation. Land degradation decreases the production of biomass and vegetation cover in every land use. Overgrazing is the general cause of desertification worldwide [15]. Overgrazing is a significant issue as local farmers have increased the number of farm animals; they have due to an increase in demand for meat in urban areas. After grazing little or nothing is done to replant herbs or grasses to cover the surface of the land, leaving it exposed to extreme atmospheric temperature and pressure. Other factors causing land degradation include urbanization, climate change, over-drafting of groundwater, deforestation, natural disasters, and tillage practices in agriculture that place soils more vulnerable to wind. Land degradation affects topsoil, human, groundwater reserves, surface runoff, animal and plant populations.

\section{Management solutions and healthy practices}

Water pollution. The public should be aware of the consequences of water pollution and can learn management skills and healthy agricultural practices which can be sufficient to achieve the aim and objective of lowering water pollution. Animals should be restricted to a controlled area, and their faces must be disposed of appropriately to prevent their contact with the water bodies as they can carry bacteria and viruses.

Toxic fertilizers such as DDT must not be used since they pose a threat to the lives of people, animals, and other wildlife. Domestic sewage and industrial wastewater with an intense concentration of pollutants ought to be treated with a highly competent sewage treatment plant to prevent water pollution [16]. Well-designed treatment plants with additional qualities should be used to treat sewage because of their competency as they have a function to remove more of these pollutants.

Air pollution. Both the federal and the state governments should develop renewable energies, if they aren't capable of this, they can give a license to foreign or individual companies who can generate renewable energy. Energy efficiency and the use of filters at the factories should be promoted. The development of public land transport, water transport, and cycling should be initiated. The government can create television and radio programs for the promotion of a healthy environment and the public to be well informed. Law on the prohibition of dangerous substances and the development of alternatives for all types of production procedures must be implemented. The example of such is:

- upgrading of Industrial Emission Standards and prevention of bush burning during the dry season;

- use of clean fuels, natural gas, electricity liquefied petroleum gas (LPG) in cities, heating stoves in rural areas;

- promotion of centralized waste collection with source separation and treatment not burning in the open;

- making sure there is full compliance with the Kigali amendment, intended to utterly phase-out Hydrofluorocarbon (HFCs) [17].

Soil degradation. In soil degradation, deforestation can be controlled. This will create a remarkable approach to restructuring and reconditioning forests and 
vegetation cover. Individuals can be well informed and educated concerning sustainable forest management and replanting endeavors. Governments, agencies, and international organizations need to make sure that there are appropriate measures for the creation of zero net on deforestation to slow down soil degradation. Proper cultivation methods serve as one of the most useful techniques for avoiding soil quality deterioration. Example is munching of the topsoil to protect it from running water and preventing poor tillage methods such as deep ploughing [18].

Flooding. Climate change has influenced and brought about the rise in extreme weather conditions. It is now crucial that world leaders and governments deliver on the promise of Paris [19]. The pressure is now on the Nigerian government to reverse its catastrophic environmental policies. The Nigerian government must "advance its flood warning systems," giving people more time to act during flooding and saving lives.

Advance notification can significantly reduce the impact of flooding. The formation of more swamplands which can act as sponges soaking up moisture and perfect advanced drainage systems can slow down waters when rivers overflow. Soil misuse, heavy duty machines, and animal hooves can cause the soil to turn out to be compacted, instead of absorbing moisture water runs off it immediately. Drained soil can absorb vast quantities of rainwater, preventing it from running into rivers and making the rivers overflow.

Land degradation. The re-growing vegetation and planting of grasses can stop heavy rains from damaging the land as vegetation and grasses help it protect the topsoil from being washed away. Planting of trees can prevent running water as running water causes rapid soil movement and erosion. The branches and leaves of trees serve as a canopy sheltering covering the soil. The protruded roots of trees and plants serve as bumps to slow down the speed of running water from washing away the topsoil, soil nutrients, and microorganisms.

The Nigerian Ministry of Environment and Agriculture should create special educative programs to reorient local farmers in the rural villages of the Southeastern states of Nigeria on the consequences of leaving a whole area of land unprotected because leaving a large area of land unprotected can bring about harmful effects on the soil.

The cost of fertilizers should be subsidized so that farmers would be able to purchase them. Fertilizers, farmyard manure, can make the soil healthy and more resistant to soil erosion. Careful disposal of industrial waste can bring about safety and sustainability of large area of land. The total avoidance and decrease in land degradation have become a vital task in the protection of our environment and eco-system at large.

\section{Challenges of effective environmental management solutions}

Cost of project implementation. It is vital for the Nigerian regulatory body and industrial unions to create a means of decreasing the price as well as the paperwork involved in environmental management. To minimize the cost of implementation, it would be vital for these regulatory bodies to assist environmental management agencies and voluntary groups to collaborate in fostering and creating environmental management policies and systems. 
It would be significant for the Nigerian regulatory body to encourage environmental management system implementation by involving some of its officers to aid and support firms planning to implement the system or during the review or after implementation.

Human resources. Experienced skill is mandatory for effecting any management system. The availability of experienced human resources is a significant limitation all through the implementation of management systems. Lack of skilled human resources is a substantial hindrance in implementing a good management system.

Understanding and assessment. Most times, there are practical and functional difficulties such as how to classify the environmental characteristics and their related impacts, how to estimate the consequence of ecological effects, decrease the progress of environmental implementation.

Documentation. Large paperwork which comprises of the development of the instruction booklet, emergency plan, technique, operation control procedures, checklist, and record keeping, etc., require more time to make available and developed. Review, updating, and control of documents require more effort if the organization is too large.

\section{Conclusion}

Environmental degradation is the main reason natural environments in Southeastern Nigeria are compromised in some way, bringing about a reduction in biological diversity and the general health of the environment at large. This process has been accelerated or caused by human activities. From the period natural resources were discovered in the southeastern regions, people have exploited natural resources leading to a decline in environmental quality. The rising health experiences due to flooding, air pollution, land and soil pollution, soil erosion, and water pollution significantly show that environmental condition is worsening.

The worsening condition of the natural environment in the southeastern regions is viewed as a significant risk to human safety. These risks include intensifying exposure to communicable and contagious diseases, lack of clean potable water, food shortage, and natural disasters. Change in the natural habitat brings about the decline of human health as natural existing microorganisms responsible for specific functions in the ecosystem perish leaving a big vacuum which can cause instability in the natural existence of the environment. For instance, environmental changes as climate change, land and soil degradation, and aquifer depletion immensely influence agricultural production.

Not until the Federal Government and all other government agencies act, the southeastern regions will soon turn out to be inhabitable as the rate of environmental decline is on the increase. Ecological changes that precisely influence the state of human health include the rise in temperature and emission of harmful fumes, which causes respiratory problems and waterborne diseases. New solutions in the implementation of environmental policies will go a long way helping to restore the integrity of the natural environment of the southeastern regions. 


\section{References}

[1] NAN. Federal approves N5.56bn for erosion control in six states. The Guardian. 2017, November 8. Available from: https://guardian.ng/news/fg-approves-n5-56bn-for-erosioncontrol-in-six-states (accessed: 20.09.2019).

[2] Madu IA. Spatial Inequality in Nigeria: The Imperative of Geographic Perspectives in the Development Process. Journal of Social and Economic Development. 2006;8(0.2): $105-120$.

[3] Okonkwo E. Traditional Methods of Preserving Dead Human Bodies in Southeastern Nigeria. ResearchGate; 2014, May. Available from: https:/www.researchgate.net/publication/ 273951379_Traditional_Methods_of_Preserving_Dead_Human_Bodies_in_Southeaste rn_Nigeria (accessed: 20.09 .2019$)$.

[4] Monanu P. Temperature and Sunshine: In Nigeria in Maps. Benin City, Ethiope Publishing House; 1975.

[5] Monanu P. Humidity. In Nigeria in Maps: Eastern States. Ofomata, Ethiope Publishing House; 1975. p. 16-18.

[6] Lozano RNM. Global and regional mortality from 235 causes of death for 20 age groups in 1990 and 2010: A systematic analysis for the Global Burden of Disease Study 2010. PubMed; 2012, December 15. Available from: https://www.ncbi.nlm.nih.gov/pubmed/ 23245604 (accessed: 20.09.2019).

[7] WHO. World health Indoor air quality guidelines: household fuel combustion. Geneva, Switzerland. 2014. Available from: https://books.google.ru/books?hl=ru\&lr=\&id=Hlk0 DgAAQBAJ\&oi=fnd\&pg=PP1\&dq=WHO.+World+health+Indoor+air+quality+guidel ines:+household + fuel+combustion\&ots $=$ LhrFikMbHJ\&sig $=1 x S 6 Z m v K n G 1 X 4 d m e-D Z$ c0ZfElfw\&redir_esc $=\mathrm{y} \# \mathrm{v}=$ onepage $\& \mathrm{q}=\mathrm{WHO} \% 20 \mathrm{~W}$ orld $\% 20$ health $\% 20$ Indoor $\% 20$ air $\% 20$ quality $\% 20$ guidelines $\% 3 \mathrm{~A} \% 20$ household $\% 20$ fuel $\% 20$ combustion $\& \mathrm{f}=$ false (accessed: 20.09.2019).

[8] Egbedi H. Welcome to Onitsha: the city with the world's worst air. The Guardian. 2017, February 13. Available from: https://www.theguardian.com/cities/2017/feb/13/ polluted-Onitsha-Nigeria-perpetual-dust-city-world-worst-air (accessed: 20.09.2019).

[9] Alexander RH. Wind as the primary driver of erosion in the Qaidam Basin, China. Earth and Planetary Science Letters. 2013, July 15. Available from: https:// www.sciencedirect.com/science/article/pii/S0012821X13001325 (accessed: 20.09.2019).

[10] BBC. River processes. BBC bitesize guides. Available from: https://www.bbc.com/ bitesize/guides/zq2b9qt/revision/1 (accessed: 20.09.2019).

[11] Ashraf SI. Impact of soil erosion and degradation on water quality: a review. Geology, Ecology, and Landscapes. 2017, March 20. Available from: https://www.tandfonline.com/ doi/full/10.1080/24749508.2017.1301053 (accessed: 20.09.2019).

[12] Tolulope AF, Adebusuyi A. Impact of Poor Land Utilization on Sustainable Human Development in Ado-Odo/Ota of Ogun State, Nigeria. Available from: www.sciencedomain.org: http://www.journalrepository.org/media/journals/ARJASS_45/2016/Jun/Fajobi1 12016 ARJASS26998.pdf (accessed: 20.09.2019).

[13] Nigeria floods kill more than 100. BBC News. 2018, September 17. Available from: https://www.bbc.com/news/world-africa-45546695 (accessed: 20.09.2019).

[14] Gong L, Hou S, Su B, Miao K et al. Short-term effects of moderate and severe floods on infectious diarrheal diseases in Anhui Province, China. PubMed; 2019, April 17. Available from: https://www.ncbi.nlm.nih.gov/pubmed/31030148 (accessed: 20.09.2019).

[15] Biswajeet PM. A New Approach for Land Degradation and Desertification Assessment Using Geospatial Techniques. ResearchGate; 2017, October. Available from: https:// www.researchgate.net/publication/320335122_A_New_Approach_for_Land_Degradation and_Desertification_Assessment_Using_Geospatial_Techniques (accessed: 20.09.2019).

[16] Causes And Solutions To Water Pollution Environmental Sciences Essay. UKeassys; 2018, November. Available from: https://www.ukessays.com/essays/environmental- 
sciences/causes-and-solutions-to-water-pollution-environmental-sciences-essay.php (accessed: 20.09.2019).

[17] Wyns A. 25 solution to air pollution. Climate tracker; 2018, October 30. Available from: http://climatetracker.org/25-solutions-to-air-pollution (accessed: 20.09.2019).

[18] Grant K. 10 measures that must be taken to prevent more flooding in the future. Independent. 2015, December 29. Available from: https://www.independent.co.uk/news/ uk/10-measures-that-must-be-taken-to-prevent-more-flooding-in-the-future-a6788866.html (accessed: 20.09.2019).

[19] Agwu A, Avoaja AG, Kalu AU. The Assessment of Drinking Water Sources in Aba Metropolis, Abia State, Nigeria. Resources and Environment. 2013;3(4):72-76. doi: 10.5923/ j.re.20130304.02.

\title{
Article history:
}

Received: 02.11.2019

Revised: 20.11.2019

\section{For citation:}

Kalu NN, Zakirova YL. A review in Southeastern Nigeria: environmental problems and management solutions. RUDN Journal of Ecology and Life Safety. 2019;27(3):231-240. http://dx.doi.org/10.22363/2313-2310-2019-27-3-231-240

\section{Bio notes:}

Nwankwo Nnabueze Kalu - postgraduate student of Applied Ecology Department of Ecological Faculty, Peoples' Friendship University of Russia (RUDN University). E-mail: esteemedthelson@yahoo.com

Yulia L. Zakirova - Candidate of Philology, Associate Professor of Department of Foreign Languages of Ecological Faculty, Peoples' Friendship University of Russia (RUDN University). E-mail: nigmatzyanova_yul@rudn.university

Научная статья

\section{Обзор юго-восточной части Нигерии: экологические проблемы и управленческие решения}

\author{
Н.Н. Калу, Ю.Л. Закирова \\ Российский университет дружбы народов \\ Российская Федераџия, 115093, Москва, Подольское шоссе, д. 8, корп. 5
}

Аннотация. Целью статьи является рассмотрение экологических проблем в юговосточной части Нигерии и их влияния на общественную деятельность и ценности. Освещаются вопросы уровня жизни и условий окружающей среды, а также возможные решения задач, связанных с сохранением окружающей среды. Изменение климата оказывает сильное влияние на юго-восточную часть Нигерии. В регионе существует целый ряд проблем, начиная от постоянных наводнений, разрушения естественной среды обитания до связанных с окружающей средой осложнений со здоровьем. Авторы отвечают на вопросы о трудностях сохранения окружающей среды и раскрывают причины их возникновения. Важным аспектом является объяснение социального поведения и рисков, которые 
влечет неосведомленность о косвенном влиянии человеческой деятельности на окружающую среду, когда в фокусе в основном находятся вопросы загрязнения воды, почвы и воздуха. В статье уделено особое внимание постоянным, наиболее устойчивым экологическим проблемам юго-восточной части Нигерии и способам их решения.

Ключевые слова: деградация почв, загрязнение окружающей среды, проблемы, управление

\section{История статьи:}

Дата поступления в редакцию: 02.11.2019

Дата принятия к печати: 20.11.2019

\section{Для цитирования:}

Kalu N.N., Zakirova Y.L. A review in Southeastern Nigeria: environmental problems and management solutions (Обзор юго-восточной части Нигерии: экологические проблемы и управленческие решения) // Вестник Российского университета дружбы народов. Серия: Экология и безопасность жизнедеятельности. 2019. Т. 27. № 3. С. 231-240. http://dx.doi.org/10.22363/2313-2310-2019-27-3-231-240

\section{Сведения об авторах:}

Калу Ннабуезе Нванкво - аспирант кафедры прикладной экологии экологического факультета, Российский университет дружбы народов. E-mail: esteemedthelson@yahoo.com

Закирова Юлия Львовна - кандидат филологических наук, доцент кафедры иностранных языков экологического факультета, Российский университет дружбы народов. E-mail: nigmatzyanova_yul@rudn.university 